\title{
Lipoprotein Secretion by Isolated Perfused Livers from Streptozotocin-Diabetic Rats
}

\author{
E. M. Berry, E. Ziv and H. Bar-On \\ Lipid Research Laboratory, Department of Medicine B, Hadassah University Hospital, Jerusalem, Israel
}

\begin{abstract}
Summary. In liver perfusion from sucrose-fed, streptozotocin-diabetic rats there was in comparison with normal animals, a decrease in very low density lipoprotein concentration in the perfusion medium $\left(38.6 \pm 6.3\right.$ versus $64.4 \pm 8.4 \mu \mathrm{g} \cdot \mathrm{g}$ liver $^{-1} 3 \mathrm{~h}^{-1}, p$ $<0.05)$ and an increase in high density lipoprotein concentration $(33.5 \pm 6.5$ versus $14.0 \pm 1.9 \mu \mathrm{g} \cdot \mathrm{g}$ liv$\mathrm{er}^{-1} 3 \mathrm{~h}^{-1}, p<0.005$ ), which was paralleled by enhanced secretion of apoprotein A-I. The triglyceride: protein ratio was lower in very low density lipoprotein from diabetic animals (8.8 versus 13.4). Analysis of the apoprotein composition showed that diabetic very low density lipoprotein lacked arginine-rich protein (apo-E) and apo-C peptides; diabetic high density lipoprotein also lacked arginine-rich protein but contained more A-IV and apo-C-peptides. This may indicate net transfer of $\mathrm{C}$ peptides to high density lipoprotein from the degradation of very low density lipoprotein particles. The ratio of ${ }^{3} \mathrm{H}$-leucine: ${ }^{14} \mathrm{C}$-glucosamine incorporation was decreased in all diabetic lipoprotein classes suggesting increased glycosylation of apoproteins. These changes in particle composition may influence lipoprotein metabolism in diabetes through their effects on lipoprotein lipase and lecithin cholesterol acyl transferase activity, plasma half-life and tissue binding.
\end{abstract}

Key words: Sucrose-feeding, streptozotocin diabetes, lipoprotein secretion, apoprotein composition, liver perfusion, incorporation of leucine, glucosamine.

It has previously been found that in experimental diabetes mellitus in the sucrose-fed rat there are increased plasma levels of very low density (VLDL), low density (LDL) and high density (HDL) lipoproteins [1]. Subsequent studies on the half-life of inject- ed HDL showed that the increase in HDL was due to an augmented synthetic rate with a secondary decrease in catabolism [2]. The mechanism for the increased VLDLlevels is thought to be due to a defect in removal caused by decreased activity of extrahepatic lipoprotein lipase [3]. Recently the presence of a plasma factor which interferes with the removal of VLDL-triglyceride has been demonstrated in experimental diabetes mellitus [4]. The parallel increase in both VLDL and HDL concentrations is of interest since there is usually an inverse relationship between these lipoproteins [5] and because the HDL particle is partially derived from the metabolism of VLDL [6]. We have previously shown that in the perfused liver from diabetic rats the incorporation of leucine into protein was decreased whilst that of glucosamine was unchanged or even enhanced [7]. We therefore wished to extend this work by examining the incorporation of these labels into the specific lipoproteins in the study of the hyperlipidaemia of experimental diabetes.

We have measured the secretion of lipoproteins by isolated perfused livers in streptozotocin-diabetic rats to assess how much hepatic synthesis determines the levels of circulating lipoproteins without the influence of peripheral catabolism by lipoproteins lipase.

\section{Materials and Methods}

\begin{abstract}
Animals and Diet
Male rats of the Hebrew University strain, weighing $250-350 \mathrm{~g}$ were fed a semi-purified sucrose rich diet consisting of $20 \%$ vitamin-free casein, $60 \%$ sucrose, $5 \%$ lard, $1 \%$ vitamin mixture, $4 \%$ salt mixture and $10 \%$ cellulose. The rats were fed for 3 weeks before induction of diabetes. Streptozotocin ( $40 \mathrm{mg} / \mathrm{kg}$ body weight) was injected into the tail vein as previously described [1]. Experiments were performed 2-4 days after the streptozotocin injection. In all the diabetic animals blood glucose concentration was over $19 \mathrm{mmol} / \mathrm{l}$.
\end{abstract}


Table 1. Lipoprotein protein in perfusates from diabetic and non-diabetic rats after perfusion for $3 \mathrm{~h}$

\begin{tabular}{llllr} 
& VLDL & LDL & HDL & Apoprotein A-I \\
\cline { 2 - 5 } & \multicolumn{4}{c}{$(\mu \mathrm{g} / \mathrm{g}$ liver $)$} \\
\hline Diabetic rats & $38.3 \pm 6.3(10)$ & $6.1 \pm 0.8(10)$ & $33.5 \pm 6.5(6)$ & $13.4 \pm 2.4(5)$ \\
Non-diabetic rats & $64.4 \pm 8.4(7)$ & $10.1 \pm 1.9(9)$ & $14.0 \pm 1.9(12)$ & $8.6 \pm 1.6(5)$ \\
$p$ & $<0.05$ & NS & $<0.005$ & NS \\
\hline
\end{tabular}

Results expressed as mean \pm SEM; number of experiments in parentheses; $\mathrm{NS}=$ not significant

\section{Liver Perfusion}

Isolated liver perfusion was performed as described by Mortimore et al. [8], published in detail [7]. The perfusate consisted of KrebsRinger bicarbonate ( $\mathrm{pH} 7.4$ ) containing glucose $4 \mathrm{mg} / \mathrm{ml}$, streptomycin $0.1 \mathrm{mg} / \mathrm{ml}$, penicillin $1000 \mu / \mathrm{ml}$, bovine serum albumin $30 \mathrm{~g} / \mathrm{l}$, a mixture of the naturally occurring amino-acids (excluding leucine) $0.1 \mathrm{mmol} / \mathrm{l}$ of each, and heparin $1 \mathrm{u} / \mathrm{ml}$. Human red blood cells, washed twice with $0.154 \mathrm{~mol} / 1$ saline (pH 7.4), were added to the perfusate to achieve a haematocrit of approximately $20 \%$. The liver was washed first with $40 \mathrm{ml}$ Krebs-Ringer bicarbonate solution. After washing, the liver was perfused in a recycling system with a volume of $60-70 \mathrm{ml}$. Throughout the perfusion, sodium palmitate complexed with serum albumin $(4: 1$ molar ratio) was infused into the portal vein at a rate of $0.2 \mathrm{mmol} / \mathrm{h}$, using a constant perfusion pump [9]. Oxygenation with $95 \% \mathrm{O}_{2}, 5 \% \mathrm{CO}_{2}$, was carried out as described by Hamilton et al. [10] using silastic tubing (DowCorning, Michigan). At zero time, $50 \mu \mathrm{Ci}$ of $\left({ }^{3} \mathrm{H}\right)$ leucine and $10 \mu \mathrm{Ci}$ of $\left({ }^{14} \mathrm{C}\right)$ glucosamine were added to the perfusate immediately after washing. Samples of perfusate were taken for the determination of apoprotein A-I, at zero time, and every 30 min thereafter for $3 \mathrm{~h}$. At the end of the perfusion the perfusate was centrifuged and the supernatant measured and stored at $5{ }^{\circ} \mathrm{C}$ after the addition of sodium azide $(1 \mathrm{mg} / \mathrm{ml})$ and EDTA $(2.1 \mathrm{mmol} / \mathrm{l})$.

\section{Separation of Lipoproteins}

Lipoproteins were isolated by the method of Havel et al. [11], using the Ti50, Ti60 or SW 41 rotors in the Beckman model L-50 ultracentrifuge at $15^{\circ} \mathrm{C}$. VLDL of $\mathrm{d} 1.006$ and LDL, $\mathrm{d} 1.006-1.063$, were separated by $20 \mathrm{~h}$ ultracentrifugation at $200,000 \mathrm{~g}$, while HDL of d $1.063-1.21$ were spearated after $40 \mathrm{~h}$ at the same speed. Densities above 1.006 were adjusted by the addition of $\mathrm{KBr}$ solutions. The isolated fractions were separated using a Spinco tube slicer, washed once by resuspending them in their respective density solutions and then repeating the ultracentrifugation. The washed lipoprotein fractions were exhaustively dialysed against water with $0.134 \mathrm{mmol} / 1$ EDTA pH 7.0 at $4^{\circ} \mathrm{C}$.

To obtain apolipoproteins free of lipid the isolated fractions were lyophilised and delipidated at $4{ }^{\circ} \mathrm{C}$ with a mixture of $3: 1 \mathrm{ab}$ solute ethanol : anhydrous diethyl-ether, as described by Brown et al. [12]. Cold ether was then added to the mixture to adjust it to $1: 1$ ethanol (v/v) [13]. The precipitate was centrifuged at $4{ }^{\circ} \mathrm{C}$ at $1000 \mathrm{~g}$ for $45 \mathrm{~min}$. The delipidated apolipoproteins were then dissolved in $0.2 \mathrm{~mol} / 1$ Tris HCL buffer ( $\mathrm{pH} 8.2$ ) containing $0.006 \mathrm{~mol} / 1$ sodium dodecyl sulphate.

\section{Chemical Methods}

Lipoprotein lipids were extracted in $99 \%(\mathrm{v} / \mathrm{v})$ isopropanol and triglyceride and cholesterol levels were determined by the Technicon autoanalyser II method [14]. The coefficient of variation for these determinations never exceeded $6 \%$. Lipoprotein protein was measured according to the method of Lowry et al. [15]. Apoprotein A-I levels were estimated by radioimmunoassay [16]. The intra-assay coefficient of variation was $4.5 \%$ and the inter-assay coefficient was $6 \%$. Protein radioactivity of the erythrocyte free perfusate and the lipoprotein fractions were determined by the method of Mans and Novelli [17].

\section{Sodium Dodecyl Sulphate (SDS) Polyacrylamide-Gel Electrophoresis}

This was performed according to the method of Shapiro et al. [18], as subsequently modified by Maizel [10]. Ten percent polyacrylamide gels were polymerized in tubes and a continuous buffer system consisting of $0.1 \mathrm{~mol} / 1$ sodium phosphate $(\mathrm{pH} 7.0)$ containing $0.1 \%$ SDS was used. Electrophoresis was carried out for a $20 \mathrm{~h}$ period at $30 \mathrm{~V}$, with the temperature maintained at $15^{\circ} \mathrm{C}$ and $20-40 \mu \mathrm{g}$ of protein being applied to each gel. The gels were stained with $0.2 \%$ Coomassie Blue in 50\% methanol and 99\% acetic acid for 20-24 h. Densitometric scanning of gels was recorded by a Quick Quant II scanner (Helena Laboratories, Beaumont, Texas, USA). With the exception of apoprotein A-I levels, identification of the different apoproteins was based solely on their different mobilities using the nomenclature of Swaney et al. [20].

\section{Materials}

L- $\left(4,5-{ }^{3} \mathrm{H}\right)$-leucine $\quad 60.0 \mathrm{Ci} / \mathrm{mmol}, \quad \mathrm{D}-\left(1-{ }^{14} \mathrm{C}\right)$-glucosamine 59.0 $\mathrm{mCi} / \mathrm{mmol}$ were purchased from the Radiochemical Centre, Amersham, UK. Streptozotocin was kindly supplied by Dr. W. Dulin of the Upjohn, Kalamazoo, Michigan, USA.

\section{Statistical Analysis}

The statistical significance of the difference between the means of the experimental groups was evaluated using Student's t-test (twotailed).

\section{Results}

\section{Lipoproteins Isolated from the Perfusate}

Table 1 shows the protein content of the different lipoprotein fractions isolated after three hours liver perfusion. VLDL levels were decreased in the diabetic preparations and HDL levels were increased. There were no significant differences in the levels of LDL or apoprotein A-I (apo-A-I). The secretion of apo-A-I, 
however, was higher in the perfusates from the diabetic animals during the whole time-course of the experiment, parallel with the raised HDL levels (Fig. 1). LDL protein levels were approximately $16 \%$ of the VLDL protein in each group.

\section{Cholesterol and Triglyceride Content of VLDL (Table 2)}

Livers from diabetic animals secreted significantly less cholesterol and triglyceride matching the de-

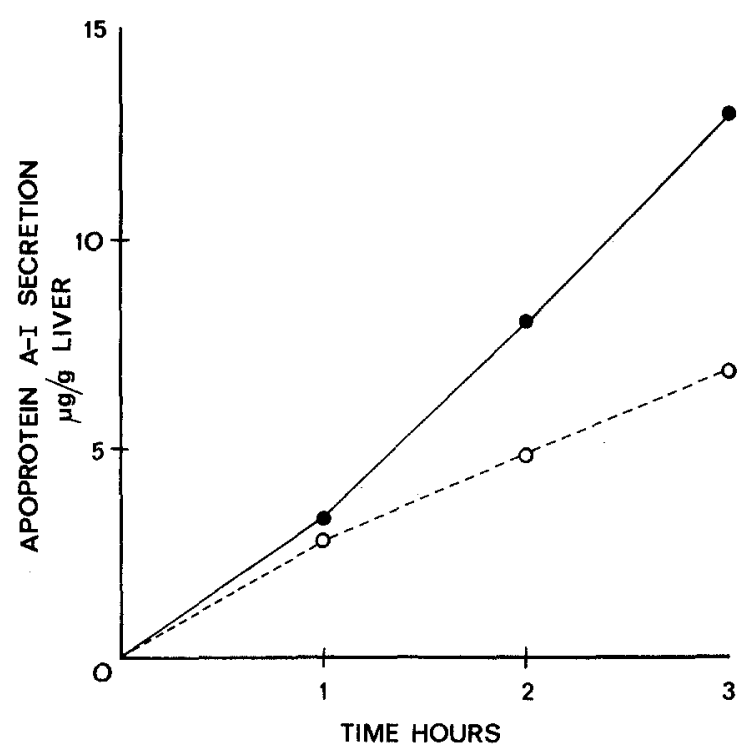

Fig. 1. The secretion of apoprotein-A-I into the perfusate during $3 \mathrm{~h}$ of isolated liver perfusion of non-diabetic $(\mathrm{O}----\mathrm{O})$ and diabetic (_-_ rats. Apoprotein A-I was determined by radioimmunoassay on perfusate samples taken hourly. Each curve is a representative of two liver perfusions

Table 2. Triglyceride and total cholesterol secretion in VLDL after liver perfusion for $3 \mathrm{~h}$

\begin{tabular}{lll}
\hline & $\begin{array}{l}\text { Triglyceride } \\
(\mu \mathrm{g} / \mathrm{g} \text { liver })\end{array}$ & $\begin{array}{l}\text { Cholesterol } \\
(\mu \mathrm{g} / \mathrm{g} \text { liver })\end{array}$ \\
\hline Diabetic rats & $336 \pm 65$ & $17 \pm 3$ \\
Non-diabetic rats & $864 \pm 15$ & $56 \pm 9$ \\
$p$ & $<0.001$ & $<0.005$ \\
\hline
\end{tabular}

Results expressed as mean \pm SEM; six experiments in each group crease in VLDL protein. The triglyceride : protein ratio in the VLDL from the diabetic preparations was $8.8 \pm 1.3$ and in the fraction from control animals $13.4 \pm 2.5$. The triglyceride: cholesterol ratios were $20.3 \pm 6.4$ and $15.5 \pm 5.1$, respectively.

\section{Specific Activities of Radioactive Labels in Different Lipoproteins}

The specific activities of ${ }^{3} \mathrm{H}$-leucine and ${ }^{14} \mathrm{C}$-glucosamine in the different lipoprotein subclasses are shown in Table $3 .{ }^{3} \mathrm{H}$-Leucine specific activity was significantly lower in all lipoproteins isolated from diabetic animals. ${ }^{14} \mathrm{C}$-glucosamine specific activities were similar in both groups. ${ }^{3} \mathrm{H}$-leucine $:{ }^{14} \mathrm{C}$-glucosamine ratios (Table 4) were significantly lower in all lipoproteins in the diabetic groups. A comparison was made of the percentage of the proteins which were secreted as lipoproteins (Table 5). The percentage ${ }^{3} \mathrm{H}$-leucine incorporation into VLDL and LDL was unchanged, while in HDL it was increased but this did not reach statistical significance. The percentage incorporation of ${ }^{14} \mathrm{C}$-glucosamine was higher in diabetic HDL but similar in VLDL and LDL.

\section{The Results of the Lipoprotein Electrophoresis}

Sodium dodecyl sulphate-polyacrylamide disc gel electrophoresis of VLDL is shown in Figure 2, together with the densitometric scan. The gels are representative of at least eight different experiments, all with similar patterns. VLDL from diabetic animals lacked arginine rich protein and apo-C peptides but contained equal if not more apoprotein A-IV. HDL from diabetic preparations also lacked arginine rich protein but contained more apoprotein A-IV and apo-C than the non-diabetic lipoprotein.

\section{Discussion}

In the perfusates from streptozotocin-diabetic rats there were significantly decreased amounts of VLDL protein but increased levels of HDL. VLDL-protein secretion in non-diabetic rats was $21.5 \mu \mathrm{g} \cdot \mathrm{g}^{-1} \mathrm{~h}^{-1}$

Table 3. The specific activity of ${ }^{3} \mathrm{H}-$ leucine and ${ }^{14} \mathrm{C}$-glucosamine in lipoproteins isolated after liver perfusion for $3 \mathrm{~h}$

\begin{tabular}{|c|c|c|c|c|}
\hline Density & & $\begin{array}{l}\text { Non-diabetic rats } \\
\text { (cpm/ } \mu \text { g protein) }\end{array}$ & $\begin{array}{l}\text { Diabetic rats } \\
\text { (cpm/ } / \mathrm{g} \text { protein) }\end{array}$ & $p$ \\
\hline $1.006,1.063$ & $\begin{array}{l}{ }^{3} \mathrm{H} \text {-leucine } \\
{ }^{14} \mathrm{C} \text {-glucosamine }\end{array}$ & $\begin{array}{r}722 \pm 192 \\
90 \pm 18\end{array}$ & $\begin{array}{r}133 \pm 43 \\
54 \pm 4\end{array}$ & $\begin{array}{l}<0.05 \\
\text { NS }\end{array}$ \\
\hline 1.21 & $\begin{array}{l}{ }^{3} \mathrm{H} \text {-leucine } \\
{ }^{14} \mathrm{C} \text {-glucosamine }\end{array}$ & $\begin{array}{r}121 \pm 27 \\
19 \pm \quad 2\end{array}$ & $\begin{array}{l}26 \pm 12 \\
18 \pm 8\end{array}$ & $\begin{array}{l}<0.05 \\
\text { NS }\end{array}$ \\
\hline
\end{tabular}

Mean \pm SEM of four observations 
which compares with values of $39 \mu \mathrm{g} \cdot \mathrm{g}^{-1} \mathrm{~h}^{-1}$ found by Marsh [21] in a non-recycling preparation and $58 \mu \mathrm{g} \cdot \mathrm{g}^{-1} \mathrm{~h}^{-1}$ calculated from the results of Ruderman et al. [22] using a haemoglobin-free system. Triglyceride secreted during liver perfusion in fed rats are all in the VLDL fractions [23] and VLDL-triglyceride production of $288 \mu \mathrm{g} \cdot \mathrm{g}^{-1} \mathrm{~h}^{-1}$ (Table 2) compares with the results obtained by these groups of 283 and $290 \mu \mathrm{g} \cdot \mathrm{g}^{-1} \mathrm{~h}^{-1}$ respectively. The reasons for the lower rates of VLDL-protein synthesis are not clear but may be related to differences in the strain of rats and their diet. Sucrose feeding increases the ratio of triglyceride : protein in VLDL [1].

In their studies on perfused livers from alloxan-diabetic rats, Heimberg et al. have also noted decreased trigylceride output and apoprotein synthesis $[24,25]$ but there has been little work on changes in the different lipoprotein subclasses in experimental diabetes.

The levels of LDL found in the perfusates probably reflected catabolism of VLDL during the course of the experiments. Recycling of labelled VLDL in the perfusion apparatus without a liver did not lead to any degradation of the lipoprotein which suggests that any changes observed were due to hepatic synthesis and/or catabolism. Circulating LDL is considered to be formed principally from the metabolic conversion of VLDL $[26,27]$. In both the diabetic and non-diabetic preparations, LDL levels were approximetely $16 \%$ those of VLDL suggesting that the hepatic fractional catabolism of VLDL was the same.

Since it has yet to be satisfactorily demonstrated that the liver secretes HDL particles, interpretation of the increased levels of this lipoprotein found in the perfusates is not clear. The increased levels of apopro-

Table 4. The ratio of ${ }^{3} \mathrm{H}$-leucine $:{ }^{14} \mathrm{C}$-glucosamine incorporated into lipoproteins isolated after liver perfusion for $3 \mathrm{~h}$

\begin{tabular}{|c|c|c|}
\hline & $\begin{array}{l}\text { Lipoprotein } \\
\text { fractions of density } \\
1.006 \text { and } 1.063\end{array}$ & $\begin{array}{l}\text { Lipoprotein fraction } \\
\text { of density } 1.21\end{array}$ \\
\hline Diabetic rats & $2.5 \pm 0.9$ & $1.8 \pm 0.4$ \\
\hline Non-diabetic rats & $7.4 \pm 0.8$ & $5.6 \pm 0.7$ \\
\hline$p$ & $<0.02$ & $<0.01$ \\
\hline
\end{tabular}

Mean \pm SEM of four observations tein A-I suggest enhanced synthesis de novo by the liver which would be in agreement with metabolic studies in the whole animal [2]. Alternatively, the HDL may be derived from increased degradation of VLDL [6], especially in the presence of heparin in the perfusate.

The decreased specific activity of ${ }^{3} \mathrm{H}$-leucine in VLDL (Table 3) was in agreement with the decreased total levels of this lipoprotein in the perfusates. The situation for HDL is, however, less clear. Whilst the total HDL concentration was elevated, the specific activity of leucine was decreased, even though the amount of HDL secreted as a percentage of the total protein was increased (Table 5). These apparently contradictory observations may be explained by either increased turnover of HDL protein or perhaps by the apoproteins of HDL from diabetic animals containing less leucine.

Whilst lipoprotein synthesis as shown by ${ }^{3} \mathrm{H}-\mathrm{leu}-$ cine incorporation was decreased in all fractions from the diabetic animals there was no change in the ${ }^{14} \mathrm{C}$ glucosamine incorporation (Table 3). The lowered ratio of ${ }^{3} \mathrm{H}$-leucine $:{ }^{14} \mathrm{C}$-glucosamine in lipoprotein from diabetic livers, suggests that there is increased glycosylation of apoproteins in diabetes (Table 4). Enhancement of the incorporation of glucosamine into secretory proteins by the perfused diabetic liver has been described previously [7]. When incorporation of the radioactive labels was expressed as a percentage of the total secreted protein, there was an increase in the ${ }^{14} \mathrm{C}$-glucosamine content of $\mathrm{HDL}$ from diabetic rats. This may reflect increase in apo-C proteins which are rich in carbohydrate residues [28]. We believe that these changes in incorporation are due to the diabetic state and are not secondary to alterations in the pool sizes of leucine and glucosamine. The pool sizes have been measured in hepatocyte preparations and were found to be similar with respect to leucine but slightly increased for glucosamine in the diabetic animals [7].

The composition of newly secreted VLDL is practically the same as that of circulating lipoprotein apart from the content of apo-C proteins which probably play only a minor role in its structural integrity $[27,29$, 30]. However, VLDL from the perfusates of diabetic

Table 5. Percentage of total trichloroacetic acid precipitated material secreted as lipoprotein estimated by ${ }^{3} \mathrm{H}$-leucine and ${ }^{14} \mathrm{C}$-glucosamine counts per minute after liver perfusion for $3 \mathrm{~h}$

\begin{tabular}{|c|c|c|c|c|}
\hline Density & & Non-diabetic rats & Diabetic rats & $p$ \\
\hline \multirow[t]{2}{*}{$1.006,1.063$} & ${ }^{3} \mathrm{H}$-leucine & $0.51 \pm 0.04$ & $0.37 \pm 0.08$ & NS \\
\hline & ${ }^{14} \mathrm{C}$-glucosamine & $0.27 \pm 0.03$ & $0.25 \pm 0.07$ & NS \\
\hline \multirow[t]{2}{*}{1.21} & ${ }^{3} \mathrm{H}$-leucine & $0.071 \pm 0.01$ & $0.176 \pm 0.05$ & NS \\
\hline & ${ }^{14} \mathrm{C}$-glucosamine & $0.048 \pm 0.001$ & $0.067 \pm 0.005$ & $<0.02$ \\
\hline
\end{tabular}

Mean \pm SEM four observations 


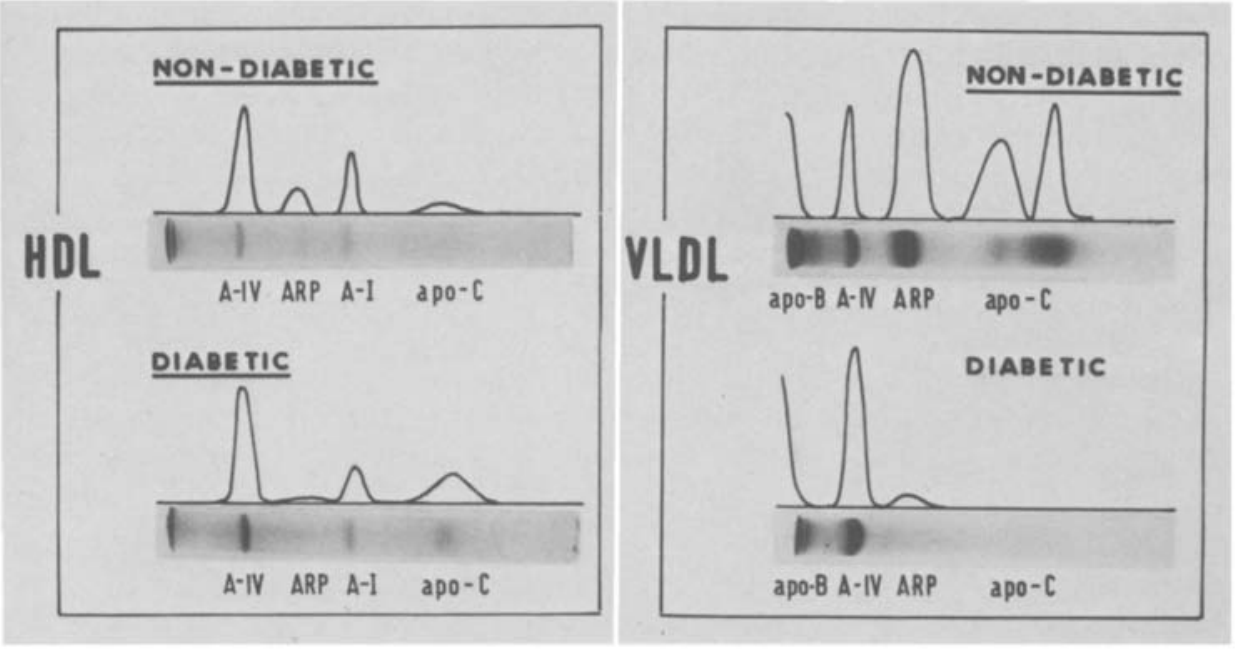

Fig. 2. Sodium dodecyl sulphate electrophoresis of high density lipoprotein (HDL) and very low density lipoprotein (VLDL) isolated from liver perfusates from diabetic and non-diabetic rats. A-IV = apoprotein-A-IV; ARP $=$ arginine-rich protein; $\mathrm{A}-\mathrm{I}=$ apoprotein-A-I; apo-C = apoprotein $\mathrm{C}$ animals differed from that found in the circulation [31]. It was depleted in arginine-rich peptides and apo-C. There are a number of possible explanations for this. The VLDL synthesized may indeed lack apo-C or be depleted of these apoproteins during recycling of the perfusates. The latter possibility may be supported by the finding of increased C-peptides in the HDL isolated from the perfusates of diabetic livers. This was not found in the non-diabetic preparations. If the apo-C peptides in HDL were indeed derived from VLDL and exchange between these lipoproteins occurs as in normal rats $[32,33]$ then the converting enzyme was hepatic lipase. This, however, would be contrary to the findings of Elkeles and Hamberley [34], who have reported that hepatic triglyceride lipase activity in the whole animal may be different from the situation in the plasma-free isolated liver perfusion system, since serum is known to inhibit hepatic lipase [35]. The lowered triglyceride : protein ratio in VLDL isolated from the diabetic livers also suggests increased lipolysis of this lipoprotein during perfusion.

In the plasma of sucrose-fed diabetic animals, VLDL levels are raised [1] despite decreased levels in perfusates. It must therefore be postulated that extrahepatic catabolism of VLDL is the prime regulator of plasma levels in experimental diabetes. Reaven and Reaven [36] come to a similar conclusion in studies on the development of hypertriglyceridaemia in acute and chronic streptozotocin-diabetic rats. In diabetic patients, Lewis et al. [37] noted the importance of reduced extra-hepatic catabolism in controlling VLDL levels. In support of this, a reduction in lipoprotein lipase activity has been observed in insulin-deficient diabetes mellitus [38-40] as well as a defect in VLDL removal [41].
In experimental diabetes it is possible that the altered composition of VLDL also influences its own catabolism. Bar-On et al. [31] found that VLDL from diabetic rats possessed both increased amounts of apo-C- $\mathrm{III}_{3}$ which is an inhibitor of lipoprotein lipase [42] and also diminished levels of apo-C-II which is an activator of that enzyme $[35,43]$. Since apo-C-III is the only C-peptide which contains carbohydrate residues [44], it is tempting to speculate that deranged glucose metabolism in diabetes mellitus may augment synthesis of this apoprotein and thus lead to reduced turnover of VLDL. If there is also increased glycosylation of apoprotein as shown by ${ }^{14} \mathrm{C}$-glucosamine relative to ${ }^{3} \mathrm{H}$-leucine incorporation, then the plasma half-lives of the lipoproteins may be prolonged because of increased resistance to degradation and proteolysis $[45,46]$.

In the perfusates from diabetic animals, there were increased amounts of HDL protein which differed in apoprotein composition both from controls and circulating HDL. The most prominent alteration was the decrease in arginine-rich protein which is the major apoprotein in nascent HDL and which is transferred to VLDL during the lecithin-cholesterol-acyltransferase reaction $[33,47]$. In the diabetic whole animal there is a decrease in total levels of arginine-rich protein, a decrease in its content in HDL (despite raised levels of HDL) and a slight increase in VLDL. This might be explained by either increased lecithincholesterol-acyl-transferase activity or decreased synthesis or a combination of the two. Analysis of the apoprotein in the perfusates showed there to be a decrease in arginine-rich protein in both HDL and VLDL, suggesting that synthesis is indeed decreased in diabetes. Arginine-rich protein synthesis may be particularly dependent on insulin but the function of 
this apoprotein in the metabolism of VLDL-triglyceride awaits further clarification [28]. It is also possible that arginine-rich protein may be lost to the lipoprotein-free plasma during ultracentrifugation. The deletion of arginine-rich protein from HDL may cause the latter to accumulate in the perfusate, since the uptake and binding of HDL by hepatocytes is dependent on this particle containing arginine-rich protein for receptor recognition [48].

Another difference concerns apoprotein A-IV levels. In the plasma of diabetic rats, total apoprotein A-IV levels are increased [31] mainly due to an increase in VLDL; levels of this apoprotein in HDL are decreased. In the perfusates, however, there was increased apoprotein A-IV in diabetic HDL. The function of apoprotein A-IV is also unknown but it may undergo transfer to VLDL in the circulation.

Whilst the precise significance of these alterations in apoproteins in experimental diabetes is not completely understood, they may indicate a role for apoprotein synthesis and the glycosylation (arginine-rich protein, apo-B and apo-C-III) in the regulation of lipoprotein metabolism. Detailed quantitative analysis of the carbohydrate content of apoproteins in diabetes will be required to verify these suggestions. The changes in hepatic lipid synthesis which undoubtedly occur in diabetes can only be expressed systemically through binding to apoproteins $[49,50]$. The importance of altered apoprotein glycosylation in relation to lipoprotein function and the pathogenesis of diabetic microangiopathy and atherosclerosis requires further investigation.

Acknowledgements. We thank Dr. M. Fainaru for the determination of apoprotein A-I. We are grateful to Professor S. Eisenberg for his advice and criticisms. This work was supported by grant 604 from the United States-Israel Binational Science Foundation (BSF), Jerusalem, Israel, by a grant from the Joint Research Fund of the Hebrew University-Hadassah Medical School, and by a grant from Mr. M. Sirotkin, USA.

\section{References}

1. Bar-On H, Roheim PS, Eder HA (1976) Hyperlipoproteinaemia in streptozotocin-treated rats. Diabetes 25:509-515

2. Bar-On H, Eisenberg S (1978) The metabolic fate of high density lipoprotein (HDL) in the diabetic rat. Diabetologia 14: 65-69

3. Bierman EL, Bagdade J, Porte D Jr (1966) Concept of pathogenesis of diabetic lipaemia. Trans Assoc Am Phycicians 79: 348-360

4. Bar-On H, Chen YDI, Reaven GM (1980) A new mechanism for the VLDL-TG removal defect in insulin deficient rats (Abstract). Diabetes 29: $40 \mathrm{~A}$

5. Nichol AV (1969) Human serum lipoproteins and their interrelationships. Adv Biol Med Phys 11: 109-158

6. Patsch JR, Gotto AM Jr, Olivecrona T, Eisenberg S (1978) Formation of high density lipoproteinz-like particles during lipoly- sis of very low density lipoproteins in vitro. Proc Natl Acad Sci USA $75: 4519-4523$

7. Berry EM, Ziv E, Bar-On H (1980) Protein and glycoprotein synthesis and secretion by the diabetic liver. Diabetologia 19: 535-540

8. Mortimore GE, Woodside KH, Henry JE (1972) Compartmentation of free valine and its relation to protein turnover in perfused rat liver. J Biol Chem 247: 2776-2784

9. Bar-On H, Kook AI, Stein O, Stein Y (1973) Assembly and secretion of very low density lipoproteins by rat liver following inhibition of protein synthesis with cycloheximide. Biochim Biophys Acta 306: 106-114

10. Hamilton RL, Berry MN, Williams MC, Severinghaus EM (1974) A simple and inexpensive membrane "lung" for small organ perfusion. J Lipid Res 15: 182-186

11. Havel RJ, Eder HA, Bragdon JH (1955) The distribtuion and chemical composition of ultracentrifugally separated lipoproteins in human serum. J Clin Invest 34: 1345-1353

12. Brown WV, Levy RI, Fredrickson D (1970) Further characterization of apolipoproteins from human plasma very low density lipoproteins. J Biol Chem 245: 6588-6594

13. Scanu AM, Edelstein C (1971) Solubility in aequeous solutions of ethanol of the small molecular weight peptides of the serum very low density and high density lipoproteins. Relevance to the recovery problem during delipidation of serum lipoproteins. Anal Biochem 44: 576-588

14. Manual of Laboratory Operations, Lipid Research Clinics Program (1974) Vol. 1, Lipid and lipoprotein analysis, Department of Health, Education and Welfare Publication No. 75.628, Bethesda

15. Lowry OH, Rosebrough NJ, Farr AL, Randall RJ (1951) Protein measurement with the Folin phenol reagent. J Biol Chem 193:265-275

16. Fainaru M, Havel RJ, Felker TE (1976) Radioimmunoassay of apolipoprotein apoprotein A-I of rat serum. Biochim Biophys Acta 446: 56-68

17. Mans RJ, Novelli GD (1960) A convenient rapid and sensitive method for measuring the incorporation of radioactive aminoacids in proteins. Biochem Biophys Res Commun 3:540-543

18. Shapiro AL, Vinuela E, Maizel JV Jr (1967) Molecular weight estimation of polypeptide chains by electrophoresis in SDSpolyacrylamide gels. Biochem Biophys Res Commun 28: $815-820$

19. Maizel JV Jr (1971) Polyacrylamide gel electrophoresis of viral protein. In: Marmorosch K and Koprowski H (eds) Methods of virology, vol 5. Academic Press, New York, pp 179-246

20. Swaney JB, Braithwaite F, Eder HA (1977) Characterisation of the apolipoproteins of rat plasma lipoproteins. Biochemistry $16: 271-278$

21. Marsh JB (1974) Lipoproteins in a non-recirculating perfusate of rat liver. J Lipid Res 15:544-550

22. Ruderman NB, Richards KC, Valles de Bourges V, Jones AL (1968) Regulation of production and release of lipoprotein by the perfused rat liver. J Lipid Res 9: 613-619

23. Key RE, Entenman C (1961) The synthesis of "chylomicronlike" bodies and maintenance of normal blood sugars by the isolated perfused rat liver. J Biol Chem 236: 1006-1012

24. Heimberg M, Dunkerley A, Brown TO (1966) Hepatic lipid metabolism in experimental diabetes. I. Release and uptake of triglycerides by perfused livers from normal and alloxan-diabetic rats. Biochim Biophys Acta 125:252-264

25. Wilcox HG, Dishmon G, Heimberg M (1968) Hepatic lipid metabolism in experimental diabetes. IV. Incorporation of aminoacid ${ }^{14} \mathrm{C}$ into lipoprotein-protein and triglyceride. J Biol Chem 243: 666-676

26. Sigurdsson G, Nicoll A, Lewis B (1975) Conversion of very low density lipoprotein to low density lipoprotein. A metabolic 
study of apolipoprotein B kinetics in human subjects. J Clin Invest 56: $1481-1490$

27. Eisenberg S (1976) Lipoprotein metabolism and hyperlipemia. In: Paoletti R, Gotto AM Jr (eds) Atherosclerosis reviews, vol. 1. Raven Press, New York, pp. 23-61

28. Schaefer EJ, Eisenberg S, Levy RI (1978) Lipoprotein apoprotein metabolism. J Lipid Res 19:667-687

29. Mahley RW, Bersot TP, LeQuire VS, Levy RI, Windmueller HG, Brown WV (1970) Identity of very low density lipoprotein apoproteins of plasma and liver Golgi apparatus. Science $168: 380-382$

30. Marsh JB (1971) Biosynthesis of plasma lipoproteins. Biochem Soc Symp 33: 89-98

31. Bar-On H, Roheim PS, Eder HA (1976) Serum lipoproteins and apolipoproteins in rats with streptozotocin-induced diabetes. J Clin Invest 57: 714-721

32. Rubenstein B, Rubinstein D (1972) Inter-relationships between rat serum very low density and high density lipoproteins. J Lipid Res 13:317-324

33. Felker TE, Fainaru M, Hamilton RL, Havel RL (1977) Secretion of the arginine-rich and A-I apolipoproteins by the isolated perfused rat liver. J Lipid Res 18: 465-473

34. Elkeles RS, Hamberley J (1977) The effects of fasting and streptozotocin diabetes on hepatic triglyceride lipase activity in the rat. Diabetes 26: 58-60

35. LaRosa JC, Levy RI, Windmueller HG, Fredrickson DS (1972) Comparison of the triglyceride lipase of liver, adipose tissue, and post heparin plasma. J Lipid Res 13:356-363

36. Reaven EV, Reaven GM (1974) Mechanisms for the development of diabetic hypertriglyceridemia in streptozotocin-treated rats. J Clin Invest 54: 1167-1178

37. Lewis B, Mancini M, Mattock M, Chait A, Fraser TR (1972) Plasma triglyceride and fatty acid metabolism in diabetes mellitus. Eur J Clin Invest 2: 445-453

38. Nikkila EA, Huttunen JK, Ehnholm C (1977) Post heparin plasma lipoprotein lipase and hepatic lipase in diabetes mellitus. Diabetes 26: 11-21

39. Schnatz JD, Williams RH (1963) The effect of acute insulin deficiency in the rat on adipose tissue lipolytic activity and plasma lipids. Diabetes 12: 174-178

40. Bierman EL, Amaral JA, Belknap BH (1966) Hyperlipemia and diabetes mellitus. Diabetes 15:675-679
41. Van Tol A (1977) Hypertriglyceridemia in diabetic rat. Defective removal of serum very low density lipoproteins. Atherosclerosis $26: 117-128$

42. Brown WV, Baginsky ML (1972) Inhibition of lipoprotein lipase by an apoprotein of human very low density lipoprotein. Biochem Biophys Res Commun 46:375-382

43. Havel RJ, Shore VG, Shore B, Bier DM (1970) Role of specific glycopeptides of human serum lipoproteins in the activation of lipoproteins lipase. Circ Res 27: 595-600

44. Vaith P, Assmann G, Uhlenbruck G (1978) Characterization of the oligosaccharide side chain of apolipoprotein C-III from human plasma very low density lipoproteins. Biochim Biophys Acta 541: 234-240

45. Ashwell G, Morell A (1974) The dual role of sialic acid in the hepatic recognition and catabolism of serum glycoproteins. Biochem Soc Symp 40: 117-124

46. Birkeland AJ, Christensen TB (1975) Resistance of glycoproteins to proteolysis, ribonuclease-A and -B compared. J Carbohydrates-Nucleosides-Nucleotides 2: 83-90

47. Hamilton RL, Williams MC, Fielding CJ, Havel RJ (1976) Discoidal bilayer structure of nascent high density lipoproteins from perfused rat liver. J Clin Invest 58: 667-680

48. Quarfordt S, Hanks J, Scott Jones R, Shelburne F (1980) The uptake of high density lipoprotein cholesteryl ester in the perfused rat liver. J Biol Chem 255: 2934-2937

49. Avogaro P, Bon GB, Cazzolato G, Quinci GB (1979) Are apolipoproteins better discriminators than lipids for atherosclerosis? Lancet 1: 901-903

50. Cham BE (1978) Importance of apoliporpoteins in lipid metabolism. Chem Biol Interactions 20: 263 -277

Received: 30 September 1980

and in revised form: 8 June 1981

Professor Hanoch Bar-On, M. D.

Lipid Research Laboratory,

Department of Medicine B,

Hadassah University Hospital

P. O. B. 12000

Jerusalem, 91 120, Israel 